\title{
Türkiye'de Aromaterapi Uygulanarak Yapılan Lisansüstü Randomize Kontrollü Hemşirelik Çalışmalarının İncelenmesi
}

\author{
Aslı KURTGÖZ ${ }^{1}$, Selin KESKİN KIZILTEPE國 ${ }^{2}$
}

\section{ÖZ}

Amaç: Bu araştırma Türkiye'de hemşirelik alanında aromaterapi uygulanarak yapılan randomize kontrollü lisansüstü çalışmaların incelenmesi amacıyla yapılmıştır.

Gereç ve Yöntemler: Bu derleme çalışmasında, 2000-2019 yılları arasında, hemşirelikte aromaterapi yöntemlerinin kullanıldığı randomize kontrollü tezler incelenmiştir. Yüksek Öğrenim Kurumu Ulusal Tez Merkezi Veri Tabanı "randomize kontrollü" ve "hemşirelik" anahtar kelimeleri ile birbirinden bağımsız iki araştırmacı tarafından taranmıştır. Belirtilen yıllar arasında toplam 509 lisansüstü tez incelenmiştir. İncelenen tezlerin araştırmaya dahil edilme ölçütleri; randomize kontrollü tasarımda olması, aromaterapi yöntemlerinin etkinliğinin incelenmesi ve hemşirelik alanında yapılmış olmasıdır. Bu doğrultuda dahil edilme ölçütlerini karşılayan toplam 19 teze ulaşılmıştır.

Bulgular: Tezlerden 11'i doktora, 8 'i ise yüksek lisans düzeyinde yapılmış olup, çalışmaların tamamına yakınının $(\% 94,7)$ son beş yılda yapıldığı görülmüştür. Çalışmalar kapsamında en çok kullanılan aromatik yağın lavanta olduğu $(\% 78,9)$ ve lavanta yağının en fazla inhalasyon yöntemiyle $(\% 60)$ kullanıldığı belirlenmiştir. Lisansüstü hemşirelik çalışmalarının çoğunun $(\% 52,6)$ aromaterapi uygulamasının ağrı üzerine etkisini değerlendirmek amacıyla yürütüldüğü saptanmıştır.

Sonuç: Türkiye'de hemşirelik alanında yapılan randomize kontrollü lisansüstü çalışmaların tamamına yakınında aromaterapi uygulamalarının kullanım amacına göre etkili olduğu bildirilmiştir.

Anahtar Kelimeler: Hemşirelik; koku terapi; lisansüstü; randomize.

\section{Analysis of Randomized Controlled of Nursing Postgraduate Studies Which Made by Applying Aromatherapy in Turkey}

\section{ABSTRACT}

Aim: This study was done in the nursing field in Turkey in order to analyze randomized controlled of nursing postgraduate studies which made by applying aromatherapy.

Material and Method: In this review study, randomized controlled theses using aromatherapy methods in nursing were examined between 2000 and 2019. Higher Education Institution National Thesis Center Database was searched by two independent researchers with the keywords "randomized controlled" and "nursing". A total of 509 postgraduate theses were examined between the specified years. The criteria for inclusion of theses examined in the research;being in randomized controlled design, examining the effectiveness of aromatherapy methods and are conducted in the field of nursing. Accordingly, a total of 19 theses were reached that meeting the inclusion criteria.

Results: 11 of the theses have been done at the level of doctorate and 8 at the level of master's degree. It has been seen that almost all of the studies (94.7\%) have been done in the last five years. In our study, it was determined that the most used aromatic oil was lavender (78.9\%) and lavender oil was used mostly by inhalation method (60\%). It was found that most of the postgraduate nursing studies (52.6\%) were carried out to evaluate the effect of aromatherapy on pain.

Conclusion: Aromatherapy applications have been reported to be effective according to the intended use at almost all postgraduate studies that randomized controlled trials conducted in nursing in Turkey.

Keywords: Aromatherapy; nursing; postgraduate; randomized.

1 Amasya Üniversitesi, Sabuncuoğlu Şerefeddin Sağlık Hizmetleri Meslek Yüksekokulu, Amasya, Türkiye

2 Düzce Üniversitesi, Sağlık Bilimleri Fakültesi, Düzce, Türkiye 


\section{GiRiş}

Tamamlayıcı ve bütünleşik sağlık uygulamaları; iyilik halinin artırılması amacıyla çeşitli hastalıkların bakım ve tedavisinde yaygin olarak kullanılmaktadir. $\mathrm{Bu}$ uygulamalardan birisini aromaterapi oluşturmaktadır (1). Aromaterapi, bitkilerden elde edilen uçucu (esansiyel) yağların masaj, kompres, inhalasyon ve banyo gibi yollarla terapötik kullanımı olarak tanımlanmaktadır (2).

Aromaterapide; lavanta, melekotu, papatya, sardunya, çay ağacı, limon, zencefil, anason tohumu, fesleğen, kakule, tarçın, sedir ağacı, bergamot ve okaliptüs olmak üzere birçok uçucu yağ kullanılmaktadır $(3,4)$. Uçucu yağlarda bulunan kimyasallar vücuda uygulandığında emilerek dolaşım ve sinir sistemine katılmakta, böylece fizyolojik veya psikolojik etkiler göstermektedir (2). Aromaterapi, fiziksel, zihinsel ve duygusal refahı iyileştirmek için kullanılan tamamlayıcı bir sağlı uygulaması olması nedeniyle migren, bronşit, akne, artrit, sistit, grip, osteoartrit, ağrı, anksiyete ve kanserle ilişkili bazı semptomlarda sıkça kullanılmaktadır (3-5).

Esansiyel yağların kullanımı hemşirelik teorilerinin uygulama felsefesine, mesleğin etik kurallarına ve ilkelerine uygun olması sebebiyle, hasta bakımını geliştirmek ve mesleğin güçlendirmesini desteklemek amacıyla hemşireler tarafindan kullanılabilmektedir $(5,6)$. İlk kez Florence Nightingale, Kırım savaşında yaralı askerleri sakinleştirmek için askerlerin alın bölgelerine lavanta yağı uygulamıştır. Bu doğrultuda Nightingale'in hemşirelik bakımında esansiyel yağ kullanımına öncülük ettiği bilinmektedir (5). Bu bağlamda modern tıp yöntemleriyle karşılanamayan bakım gereksinimlerinin, kanıta dayalı bilgiler ışığında, tamamlayıcı yöntemlerle desteklenmesi önem kazanmaktadır (7).

Randomize kontrollü çalışmalar neden-sonuç ilişkisi hakkında en iyi bilgi ve kanıtı sağlayan çalışmalar olarak kabul edilmektedirler (8). John Hopkins Kanıta Dayalı Hemşirelik Uygulama Modeli'ne göre kanıtlar üç düzeyde sınıflandırılmakta ve bu sinıflamanın birinci düzeyinde "deneysel/randomize kontrollü çalışmalar ya da randomize kontrollü çalışmaları içeren meta analiz çalışmalarından elde edilen kanıtlar" yer almaktadır (9). $\mathrm{Bu}$ bağlamda hemşirelik alanında kanıt düzeyi yüksek kabul edilen çalışmalarla aromaterapi etkinliğinin incelenmesi ve etkinliği belirlenen aromaterapi yöntemlerinin hemşirelik uygulamalarında kullanılmasının bakım kalitesini artıracağı düşünülmektedir. Bu çalışma ile ülkemizde hemşirelik alanında aromaterapi yöntemlerinin kullanıldığı randomize kontrollü lisansüstü tez çalışmalarından elde edilen sonuçlar derlenmiştir.

\section{GEREÇ VE YÖNTEMLER}

$\mathrm{Bu}$ derleme çalışması, Türkiye'de 2000-2019 yılları arasında hemşirelik alanında aromaterapi yöntemlerinin kullanıldığı randomize kontrollü lisansüstü tez çalışmalarını değerlendirmek amacıyla, 24/03/202028/04/2020 tarihleri arasında gerçekleştirilmiştir.

Çalışmanın literatür taraması, Yükseköğretim Kurulu Ulusal Tez Merkezi Veri Tabanı'nın iki bağımsız araştırmacı tarafından incelenmesiyle gerçekleştirilmiştir. Veri taraması yapılırken "randomize kontrollü" ve "hemşirelik" anahtar kelimeleri kullanılmıştır. Bu araştırmada incelenen tezlerin araştırmaya alınma ölçütleri; araştırmada çeşitli aromaterapi yöntemlerinin etkinliğinin incelenmesi, hemşirelik alanında yapılmış olması ve araştırma tasarımının randomize kontrollü olmasıdır. Araştırma için belirlenen anahtar sözcüklerin taranması sonucu elde edilen toplam 509 tez dahil edilme kriterlerine göre değerlendirilmiştir. Araştırma, dahil edilme kriterlerini karşılayan, toplam 19 tezin incelenmesiyle yürütülmüştür. Verilerin analizinde sayısal değerlendirmeler kullanılmıştır. Analiz sonuçları frekans ve yüzde değerleriyle ifade edilmiştir. Araştırmaya dahil edilen tezler; yazar, tez yılı, çalışmanın amac1, örneklem grubu, aromaterapi kullanım yöntemi ve araştırmanın sonuçları şeklinde kronolojik sıraya göre özetlenmiştir (Tablo 1. ve Tablo 2.). Bazı çalışmalarda birden fazla tamamlayıcı uygulamanın kullanıldığı tespit edilmiştir. $\mathrm{Bu}$ nedenle araştırmanın amacı doğrultusunda çalışmalardaki aromaterapiyle ilgili uygulama ve sonuçlar belirtilmiştir.

$\mathrm{Bu}$ çalışma bir literatür araştırması olduğu için etik kurul raporu bulunmamaktadir.

\section{BULGULAR}

Araştırmaya alınan tezlerden 11'i doktora, 8'i ise yüksek lisans tezidir. Ülkemizde aromaterapi kullanılarak yapılan ilk randomize kontrollü lisansüstü tez çalışmasının 2013 tarihinde yapıldığı, (10) bununla birlikte çalışmaların (11-28) tamamına yakınının $(\% 94,7)$ son beş yılda yapıldığı belirlenmiştir.

İncelenen tezlerde aromaterapi amaciyla kullanılan esansiyel yağların lavanta, okaliptüs, tatlı portakal, ardıç, ylang ylang, biberiye, limon çimeni, ingiliz nanesi, bergamot, kakule, papatya, sarı kantaron, neroli ve nane olduğu; en çok kullanılan aromatik yağın ise lavanta olduğu $(\% 78,9)$ belirlenmiştir (Tablo 1 ve Tablo 2).

Bazı çalışmalarda $(14,15,18,21-23,26-28)$ lavanta yağı tek başına aromatik yağ olarak kullanılırken, diğer çalışmalarda $(10-13,24,25)$ ise başka aromatik yağlarla karışım oluşturularak kullanılmıştır.

Aromatik yağların dermal (diz, bacak, ayak, el, sirt), inhalasyon, topikal uygulama (oturma banyosu vs.) şeklinde kullanıldığı, en fazla kullanılan yöntemin ise inhalasyon $(\% 73,3)$ olduğu belirlenmiştir. İnhalasyon amacıyla en çok kullanılan esansiyel yağın ise lavanta yağı olduğu (\%60) saptanmıştır (Tablo 1. ve Tablo 2.).

Tablo 1'de doktora tezlerinin yazarı, yazım yılı, amac1, örneklem grubu, aromaterapi kullanım yöntemi ve sonuçları yer almaktadır. Tablo 1 incelendiğinde, araştırma kapsamına alınan doktora tezlerinin çeşitli örneklem grupları ile yürütüldüğü görülmektedir. İncelenen doktora tezlerinde araştırma kapsamına alınan örneklem grubunu; preterm yenidoğanlar, hemodiyaliz, kanser, demans, romatoid artrit, diz osteoartrit tanısı ile premenstrüel ve miyofasial ağrı sendromu olan hastalar oluşturmuştur.

Doktora tezlerinde aromaterapinin etkinliğini değerlendirmek amacıyla ele alınan konuların çoğunlukla ağr1, yorgunluk, bulantı-kusma ve anksiyete olduğu belirlenmiştir. İncelenen tez çalışmalarında aromaterapi uygulamalarının en fazla $(\% 36,3)$ kanser hastalarıyla yürütüldüğü, kemoterapiye bağlı; "bulantı- kusma", "bulantı, kusma, öğürme", "periferal nöropatik ağrıyorgunluk" ve "implante edilebilir venöz port katater işlemi sırasındaki ağrı-anksiyete" üzerine etkisi gibi 
amaçlarla ele alındığı görülmektedir. Çalışmaların \%84,2'sinde çalışmanın amacı doğrultusunda uygulanan 
Tablo 1. Doktora tezlerinin incelenmesi

\begin{tabular}{|c|c|c|c|c|}
\hline Yazar-Yıl & Araştırmanın Amacı & Örneklem Grubu & Aromaterapi Uygulama Yöntemi & Araştırmanın sonucu \\
\hline Tosun Ö. (2013) & $\begin{array}{l}\text { Aromaterapi, müzikterapi ve vibrasyon } \\
\text { uygulamasının yenidoğanı stres ve } \\
\text { davranışları üzerine etkisini değerlendirmek }\end{array}$ & $\begin{array}{l}80 \text { preterm yenidoğan } \\
\text { (Aromaterapi:20; Müzikterapi:20; } \\
\text { Vibrasyon:20; Kontrol: 20) }\end{array}$ & $\begin{array}{l}\text { Haftanın } 5 \text { günü, } 10 \text { dakika lavanta yağı (badem yağı } \\
\text { ile seyreltilen) kullanılarak masaj uygulanmıştrr. }\end{array}$ & $\begin{array}{l}\text { Aromaterapi uygulamasının preterm yenidoğanların stresini azalttığı ve } \\
\text { davranışlarını olumlu yönde etkilediği belirlenmiş̧tir }\end{array}$ \\
\hline Muz G. (2015) & $\begin{array}{l}\text { Hemodiyaliz tedavisi alan bireylerde } \\
\text { inhalasyon yoluyla uygulanan aromaterapinin } \\
\text { uyku kalitesi ve yorgunluk düzeyine etkisini } \\
\text { belirlemek }\end{array}$ & $\begin{array}{l}62 \text { diyaliz hastası } \\
\text { (Müdahale: } 27 \text {; Kontrol: } 35 \text { ) }\end{array}$ & $\begin{array}{l}\text { Bir ay boyunca her gün yatmadan önce aromaterapi } \\
\text { (tatlı portakal ve lavanta yağı) inhalasyonu } \\
\text { uygulanmıştr. }\end{array}$ & $\begin{array}{l}\text { Diyaliz hastalarında inhalasyon yoluyla uygulanan aromaterapinin uyku } \\
\text { kalitesini artırdığı, yorgunluk düzeyi ve şiddetini azalttığı belirlenmiştir. }\end{array}$ \\
\hline Metin ZG. (2015) & $\begin{array}{l}\text { Aromaterapi masaji ve refleksolojinin } \\
\text { romatoid artrit hastalarnda görülen ağrı ve } \\
\text { yorgunluk üzerine etkilerini incelemek }\end{array}$ & $\begin{array}{l}51 \text { romatoid artrit hastası } \\
\text { (Aromaterapi:17; Refleksoloji: 17; } \\
\text { Kontrol: 17) }\end{array}$ & $\begin{array}{l}\text { Aromatik karısıım (ardiç, tibbi lavanta, ylang ylang ve } \\
\text { biberiye yağları) her iki dize haftada üc kez } \\
\text { aromaterapi masajı (her uygulama süresi } 30 \text { dakika) }\end{array}$ & $\begin{array}{l}\text { Aromaterapi masajının romatoid artrit hastalarında ağrı ve yorgunluğu } \\
\text { azaltmada ve sağllk algisını artırmada etkili olduğu ancak sabah } \\
\text { tutukluğunu azaltmada etkili olmadığı saptanmıstır. }\end{array}$ \\
\hline Yayla EM. (2016) & $\begin{array}{l}\text { İnhaler yolla uygulanan lavanta ve okaliptüs } \\
\text { esansiyel yağlarınnn implante edilebilir venöz } \\
\text { port kateter iğne girişine bağlı prosedürel ağrı } \\
\text { ve anksiyete üzerine etkisini incelemek }\end{array}$ & $\begin{array}{l}\text { 123 kanser hastas1 } \\
\text { (Lavanta: } \quad 41 ; \quad \text { Okaliptüs:41; } \\
\text { Kontrol: } 41)\end{array}$ & $\begin{array}{l}\text { İmplante edilebilir venöz port katetere iğne giriş işlemi } \\
\text { öncesinde üç dakika boyunca üç damla tıbbi lavanta ve } \\
\text { okaliptüs esansiyel yağı kulak pamuğtna damlatılarak } \\
\text { aromaterapi inhalasyonu uygulanmıștır. }\end{array}$ & $\begin{array}{l}\text { Implante edilebilir venöz port katetere iğne giriş işlemi öncesinde } \\
\text { inhalasyon yoluyla uygulanan lavanta esansiyel yağının ağrı düzeyini } \\
\text { azalttığı saptanmışı̆. }\end{array}$ \\
\hline Kaymaz TT. (2016) & $\begin{array}{l}\text { Masaj ve inhalasyon yolu ile uygulanan } \\
\text { aromaterapinin, orta ve ileri evre demans } \\
\text { hastalarnnn ajitasyon düzeyleri ve hastalara } \\
\text { bakım veren bireylerin bakım yükü üzerine } \\
\text { olan etkisini incelemek }\end{array}$ & $\begin{array}{l}28 \text { demans hastası ve bakım } \\
\text { verenleri* } \\
\text { (Müdahele: } 14 \text {; Kontrol: } 14 \text { ) } \\
\text { *Bakm verenlere aromaterapi } \\
\text { uygulamast yaplmamıştr. }\end{array}$ & $\begin{array}{l}\text { Hastalara haftada } 3 \text { gün olmak üzere } 1 \text { ay süresince } \\
\text { limon çimeni esansiyel yağı ile aromaterapi el masaj1 } \\
\text { ve haftanın her günü lavanta esansiyel yağı ile } \\
\text { aromaterapi inhalasyonu uygulanmıștır. }\end{array}$ & $\begin{array}{l}\text { Aromaterapi el masajı ve inhalasyonu uygulamaları, demans } \\
\text { hastalarnnı ajitasyonunu azaltmada ve bakım verenlerinin bakım } \\
\text { yükünü azaltmada etkili bulunmuştur. }\end{array}$ \\
\hline $\begin{array}{l}\text { Uzunçakmak T. } \\
\text { (2016) }\end{array}$ & $\begin{array}{l}\text { Üniversite öğrencilerine uygulanan } \\
\text { aromaterapinin premenstruel sendrom (PMS) } \\
\text { ile baş etmeye etkisini belirlemek }\end{array}$ & $\begin{array}{l}77 \text { PMS olan öğrenci } \\
\text { (Deney:40; Kontrol:37) }\end{array}$ & $\begin{array}{l}\text { İnhalasyon aromaterapi yöntemi }(200 \mathrm{ml} \text { sıcak su } \\
\text { icerisine } 3 \text { damla lavanta yağı damlatılarak) her bir } \\
\text { siklus (toplam } 3 \text { siklus) için ortalama } 5 \text { seans } \\
\text { uygulanmıştr. }\end{array}$ & $\begin{array}{l}\text { İnhalasyon aromaterapi yönteminin } \\
\text { kullanılabileceği belirlenmiştir. }\end{array}$ \\
\hline Zorba P. (2016) & $\begin{array}{l}\text { Masaj ve inhaler yollarla uygulanan } \\
\text { aromaterapinin kemoterapiye bağlı akut } \\
\text { bulantt-kusmaya etkisini karşlaş̧ırmak ve } \\
\text { değerlendirmek }\end{array}$ & $\begin{array}{l}75 \text { meme kanserli kadin hasta } \\
\text { (Masaj: 25; İnhalasyon: } 25 \text {; } \\
\text { kontrol: 25) }\end{array}$ & $\begin{array}{l}\text { Masaj grubundaki hastalara, 2., 3. ve 4. kemoterapi } \\
\text { kürlerinde } 20 \text { dakika aromaterapi ayak masajı (İngiliz } \\
\text { nanesi, bergamot ve kakule esansiyel yağlarından } \\
\text { oluşan karısım); inhalasyon grubundakilere 2., 3. ve } 4 \text {. } \\
\text { kemoterapi küllerinde aynı esansiyel yağ karışııı ile } 3 \\
\text { dakika inhalasyon uygulanmıștr. }\end{array}$ & $\begin{array}{l}\text { Masaj grubunun 3. ve 4. kemoterapi kürlerinde bulantı-öğ̈̈rme yaşama } \\
\text { durumu diğer gruplara göre düşük saptanırken; masaj ve inhaler } \\
\text { aromaterapi gruplarnnda izlenen tüm kürlerde bulantı şiddetinin anlamlı } \\
\text { derecede azaldığı belirlenmiştir. }\end{array}$ \\
\hline İzgü N. (2017) & $\begin{array}{l}\text { Oksaliplatin tedavisi alan kanser hastalarında } \\
\text { el ve ayağa uygulanan aromaterapi masajinın } \\
\text { kemoterapi iliskili periferal nöropatik ağrı ve } \\
\text { yorgunluk üzerindeki etkisisin belirlemek }\end{array}$ & $\begin{array}{l}40 \text { kanser hastas1 } \\
\text { (Müdahale:20; Kontrol:20) }\end{array}$ & $\begin{array}{l}\text { 1. ve 6. haftaları arasında, haftada } 3 \mathrm{kez} \text { olmak üzere } \\
\text { toplam } 18 \text { seans aromaterapi masajı (ingiliz nanesi, } \\
\text { papatya ve biberiye) esansiyel yağları karışımı ile) } \\
\text { uygulanmıştr. }\end{array}$ & $\begin{array}{l}\text { Aromaterapi masajinn periferal nöropatik ağr görülme sıklı̆̆ı ve ağr } \\
\text { şiddetini azalttığı, yorgunluk şiddetini etkilemediği sonucuna } \\
\text { ulaşılmıştır. }\end{array}$ \\
\hline Ertürk NE. (2019) & $\begin{array}{l}\text { Kemoterapi alan hastalara uygulanan nane } \\
\text { yağınn bulantı, kusma ve öğürme üzerine } \\
\text { etkisini belirlemek }\end{array}$ & $\begin{array}{l}80 \text { kemoterapi alan hasta } \\
\text { (Müdahale:36; Kontrol: 44) }\end{array}$ & $\begin{array}{l}\text { Kemoterapi uygulamasindan hemen sonra ve takiben } 6 \\
\text { saat sonra, digger dört günde ise günde } 3 \text { defa dudak } \\
\text { üstüne \%3' lük nane yağı uygulanmiştır. }\end{array}$ & $\begin{array}{l}\text { Nane yağı uygulaması sonrası bulantı şiddetinde, bulantı, kusma ve ve } \\
\text { ögürme semptomlarnda azalma olduğu ve hastaların daha az antiemetik } \\
\text { ilaç kullandıkları belirlenmiştir. }\end{array}$ \\
\hline Sönmez DZ. (2019) & $\begin{array}{l}\text { Diz osteoartriti }(\mathrm{OA}) \text { olan bireylere diz } \\
\text { bölgesine lokal olarak uygulanan sarı } \\
\text { kantaron yağının ağrı şiddetine ve fiziksel } \\
\text { fonksiyonlara etkisi }\end{array}$ & $\begin{array}{l}60 \text { diz osteoartriti olan hasta } \\
\text { (Müdahale:30; } \quad \text { Plasebo } \\
\text { Kontrol:30) }\end{array}$ & $\begin{array}{l}\text { Diz bölgesine sarı kantaron yağı üç hafta süresince } \\
\text { günde üç kez lokal olarak sürülerek uygulanmıştır. }\end{array}$ & $\begin{array}{l}\text { Diz OA olan bireylerde sarı kantaron yağı uygulamasııın ağrıyı azaltıp; } \\
\text { fiziksel fonksiyonu arttırdığı saptanmıştır. }\end{array}$ \\
\hline
\end{tabular}


Tablo 2. Yüksek lisans tezlerinin incelenmesi

\begin{tabular}{|c|c|c|c|c|}
\hline Yazar-Yıl & Araştırmanın Amacı & Örneklem Grubu & Aromaterapi Uygulama Yöntemi & Araştırmanın sonucu \\
\hline Ayik C. (2016) & $\begin{array}{l}\text { Ameliyat öncesi dönemde aromaterapi } \\
\text { masajinn anksiyete ve uyku kalitesi üzerine } \\
\text { etkisini incelemek }\end{array}$ & $\begin{array}{l}80 \text { kolorektal cerrahi geçirecek } \\
\text { hasta } \\
\text { (Çalışma: } 40 \text {; Kontrol:40) }\end{array}$ & $\begin{array}{l}\text { Ameliyattan önceki akssam } \% 5 \text { lik lavanta yağı ile } \\
\text { ameliyat öncesi akşam } 19.00-21.00 \text { saatleri ve ameliyat } \\
\text { sabah1 06.30-08.00 saatleri arasında on dakika } \\
\text { aromaterapi masajı (sırt masajı) uygulanmışır. }\end{array}$ & $\begin{array}{l}\text { Ameliyat öncesi dönemde lavanta yağıyla uygulanan aromaterapi } \\
\text { masajnın anksiyete düzeyini azalttığı, uyku kalitesini artırdığı } \\
\text { saptanmışır. }\end{array}$ \\
\hline Eminov A. (2017) & $\begin{array}{l}\text { Epizyotomi bakımında kullanıllan lavanta yağı } \\
\text { ve buz uygulamasinın epizyotomi ağrısına, } \\
\text { yara iyileşmesine ve kadınların } \\
\text { memnuniyetlerine etkisini incelemek }\end{array}$ & $\begin{array}{l}96 \text { epizyotomi kesisi olan kadın } \\
\text { (Lavanta:32; Buz: } 31 \text {; } \\
\text { Kontrol:33) }\end{array}$ & $\begin{array}{l}\text { Doğum sonu 2. saat başlayıp günde } 2 \text { kere } 51 \text { tt suyun } \\
\text { içine (suyun 1sis: } 36,5 \text { C) } 5-7 \text { damla lavanta konularak } \\
\text { oturma banyosu yapmaları sağlanmıştır. }\end{array}$ & $\begin{array}{l}\text { Doğum sonrası kullanılan lavanta yağı uygulamasının epizyotomi } \\
\text { ağrısını azalttığı ve iyileşmeyi hızlandırdı̆ı̆ bulunmuştur. }\end{array}$ \\
\hline Cenkci Z. (2017) & $\begin{array}{l}\text { Aromaterapinin } \begin{array}{l}\text { doğum } \\
\text { Arresindeki ağrr, konfor } \\
\text { evreminin }\end{array} \text { ve memnuniyet } \\
\text { uzzerine etkisini belirlemek }\end{array}$ & $\begin{array}{l}60 \text { gebe } \\
\text { (Deney: 30; Kontrol:30) }\end{array}$ & $\begin{array}{l}\text { Aromaterapi taper (Lavanta yağı içeren bezin kadının } \\
\text { kıyafetinin yaka kısmına tutturulması) kullanılarak } \\
\text { uygulanmıştır. Taper doğum eylemi boyunca bir damla } \\
\text { lavanta yağının saatte bir yenilenmesi ile uygulanmıştır }\end{array}$ & $\begin{array}{l}\text { Aromaterapinin doğum eyleminin I. evresindeki ağrı algısını azalttığı, } \\
\text { konfor ve memnuniyet düzeyini arttırdığı bulunmuştur. }\end{array}$ \\
\hline Taşan E. (2018) & $\begin{array}{l}\text { Hemodiyaliz hastalarında damara ulaşım } \\
\text { sirasinda oluşan ağriya inhaler lavantanın } \\
\text { etkisini değerlendirmek }\end{array}$ & $\begin{array}{l}60 \text { hemodiyaliz hastası } \\
\text { (Müdahale:30; Kontrol:30) }\end{array}$ & 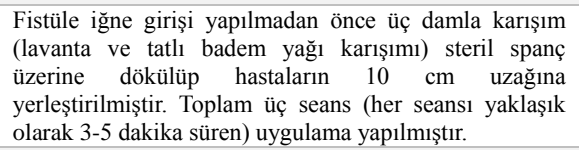 & $\begin{array}{l}\text { HD hastalarının damar girişimi sırasında yaşadıkları ağrının azalttığı } \\
\text { belirlenmiştir }\end{array}$ \\
\hline Gülşen G. (2018) & $\begin{array}{l}\text { Üst gastrointestinal endoskopi işlemi yapılan } \\
\text { hastalara müzik esliginde uygulanan inhaler } \\
\text { aromaterapinin vital bulgulara ve oksijen } \\
\text { satürasyonuna etkisini değerlendirmek }\end{array}$ & $\begin{array}{l}120 \text { hasta } \\
\text { (Müzik: } 30 \text {; Aromaterapi: } 30 \text {; } \\
\text { Müzik eşliğinde aromaterapi: } 30 \text {; } \\
\text { Kontrol: } 30 \text { ) }\end{array}$ & 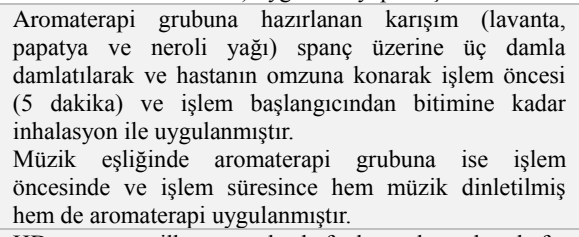 & $\begin{array}{l}\text { Müzik eşliğinde uygulanan inhaler aromaterapinin endoskopi işlemi } \\
\text { sırassinda nabız ve kan basıncını olumlu yönde etkilediği, oksijen } \\
\text { satürasyonunun düşmesini önlediği belirlenmiştir. }\end{array}$ \\
\hline Erat A. (2019) & $\begin{array}{l}\text { Hemodiyaliz tedavisi alan bireylerde lavanta } \\
\text { yağı ile uygulanan masajin huzursuz bacak } \\
\text { sendromu (HBS) şiddeti ve yaşam kalitesine } \\
\text { etkisini belirlemek }\end{array}$ & $\begin{array}{l}58 \text { hemodiyaliz hastası } \\
\text { (Müdahale:31; Plasebo:27; } \\
\text { Kontrol:27) }\end{array}$ & $\begin{array}{l}\text { HD seansının ilk yarısında, haftada üç kez, dört hafta } \\
\text { boyunca, her bacağa } 10 \text { dakika süreyle } \% 5^{\prime} \text { lik lavanta } \\
\text { yağı ile masaj uygulanmıştrr. }\end{array}$ & $\begin{array}{l}\text { Masajin HBS şiddetini ve belirtilerini azalttığı ve yaşam kalitesini } \\
\text { arttırdığı belirlenmiştir. }\end{array}$ \\
\hline Baykal FC. (2019) & $\begin{array}{l}\text { Aromaterapi masajinı kronik nonmalign } \\
\text { ağrısı olan bireylerde ağrı siddeti, kayg1 } \\
\text { düzeyi ve uyku kalitesi üzerine olan etkisini } \\
\text { belirlemek }\end{array}$ & $\begin{array}{l}40 \text { hasta } \\
\text { (Aromaterapi: } 20 \text {; Kontrol: } 20 \text { ) }\end{array}$ & $\begin{array}{l}\text { Karısıım (bebek yağı ve lavanta yağı eklenerek elde } \\
\text { edilen yağ) ile } 30 \mathrm{dk} \text {. sırt masajı yapılmıştır }\end{array}$ & $\begin{array}{l}\text { Aromaterapi masajnın kronik non-malign ağrısı olan bireylerde, ağrr } \\
\text { șiddeti, ağryyı giderme yüzdesi, kaygı düzeyi ve uyku kalitesi üzerinde } \\
\text { etkili olduğu bulunmuştur }\end{array}$ \\
\hline Özdemir ST. (2019) & $\begin{array}{l}\text { Hemodiyaliz hastalarında uygulanan lavanta } \\
\text { aromaterapinin damara erisisim sırasında oluşan } \\
\text { ağrıya etkisini değerlendirmek }\end{array}$ & $\begin{array}{l}90 \text { hemodiyaliz hastası } \\
\text { (İnhaler lavanta yağı: } 30 \text {; } \\
\text { Topikal lavanta yağı: } 30 \\
\text { Kontrol:30) }\end{array}$ & $\begin{array}{l}\text { İnhaler lavanta yağı grubunda, dilüe edilen lavanta yağı } \\
\text { bir parça pamuk üzerine } 3 \text { damla damlatıldıktan sonra } \\
\text { hastaya } 10 \mathrm{~cm} \text { uzaklıktan koklatılmıștır ( } 5 \text { dakika } \\
\text { süresince). Hastalara bu işlem } 72 \text { saat ara ile } 3 \text { kez } \\
\text { uygulanmıştır. } \\
\text { Topikal lavanta yağı grubuna } \% 100 \text { saf lavanta yağ } \\
\text { dilüe edilmeden fistül girişim bölgesine } 3 \text { damla } \\
\text { sıkılacak, } 5 \text { dakika beklenilmiştir. Hastalara bu işlem } 72 \\
\text { saat ara ile } 3 \text { kez uygulanmıştır. }\end{array}$ & $\begin{array}{l}\text { İnhaler ve topikal lavanta yağı uygulaması ile HD hastalarını damara } \\
\text { ulaşım girişimi esnasında deneyimledikleri ağrı şiddetinde anlamlı } \\
\text { oranda azalma olduğu saptanmıştr. }\end{array}$ \\
\hline
\end{tabular}


aromaterapi uygulamalarının etkili olduğu sonucuna ulaşılmıştır. Bununla birlikte Metin (12)'in yapmış olduğu çalışmada aromaterapi masajının romatoid artrit hastalarında ağrı ile yorgunluğu azaltmada ve sağlık algısını artırmada etkili olduğu, ancak sabah tutukluğunu azaltmada etkili olmadığ1; İzgü (17)'nün çalışmasında aromaterapi masajının periferal nöropatik ağrı görülme sıklığı ve ağrı şiddetini azalttığı, fakat yorgunluk şiddetini etkilemediği; Kasar (18)'ın çalışmasında ise miyofasiyal ağrı sendromu olan hastalara tetik nokta enjeksiyonu sırasında uygulanan aromaterapinin ağrı şiddetini, anksiyete ile stres düzeyini azalttığı, konfor düzeyi ve hasta memnuniyetini arttırdığı, ancak tükürük kortizol sonuçlarında anlamlı bir fark oluşturmadığı belirlenmiştir.

Tablo 2'de yüksek lisans tezlerinin yazarı, yazım yılı, amacı, örneklem grubu, aromaterapi kullanım yöntemi ve sonuçları yer almaktadır. İncelenen yüksek lisans tezlerinde araştırma kapsamın alınan örneklem grubunu; kolorektal cerrahi geçirecek hastalar, hemodiyaliz hastaları, kronik nonmalign ağrısı, epizyotomisi, doğum eylemi evresinde olan ve üst gastroendoskopi işlemi uygulanacak hastalar oluşturmuştur.

Yapılan yüksek lisans tez çalışmalarında aromaterapi uygulamalarının en fazla $(\% 37,5)$ hemodiyaliz hastalarıyla yürütüldüğü; hemodiyaliz hastalarında "damara ulaşım/erişim sırasında oluşan ağrı" ile "huzursuz bacak sendromu şiddeti ve yaşam kalitesi" üzerine etkisinin incelendiği görülmektedir. Yüksek lisans tezlerinde aromaterapinin etkinliğini değerlendirmek amacıyla ele alınan konuların çoğunlukla ağrı, uyku ve kaygı olduğu belirlenmiştir. İncelenen tüm tezlerde çalışmanın amacı doğrultunda uygulanan aromaterapi uygulamalarının etkili olduğu sonucuna ulaşılmıştır.

\section{TARTIŞMA}

Hemşirelik uygulamalarında aromaterapiye yer verilmesi, bakımın etkinliğini artırmanın yanı sıra bireylerin yaşadığı fiziksel ve psikolojik semptomların hafiflemesini ve yaşam kalitelerinin artmasını destekleyecektir (1). Aromaterapinin kanıt düzeyi yüksek bilgiler doğrultusunda uygulanması güvenli ve etkin kullanımı yönünden önem kazanmaktadır. Bu bağlamda hemşirelik alanında yapılmış kanıt düzeyi yüksek aromaterapi çalışmalarının gerekliliği ortaya çıkmaktadır. Ülkemizde hemşirelik alanında yapılmış randomize kontrollü lisansüstü çalışmalarda en sık kullanılan aromatik yağın lavanta olduğu belirlenmiştir. Lavanta yağı, esansiyel yağların hastalar üzerindeki etkilerini araştıran ilk hemşirelik çalışmalarında da sıkça kullanılmıştır (29). Literatürde lavanta yağının sakinleştirici, kas gevşetici, ferahlatıcı, kas ve baş ağrısını hafifletici, rahat uyumayı sağlayıcı, yanıkları tedavi edici özelliklerinin olduğu, inhale edildiğinde soğuk algınlığ ve gripte iyileşmeyi hızlandırdığ Yapılan tezlerde (10-15, 18, 21-28) lavanta yağının; stres, uyku kalitesi, yorgunluk, ağrı düzeyi (doğum, epizyotomi, fistüle iğne girişi esnasında hissedilen, kronik non-malign, romatoid artrit, implante edilebilir venöz port katatere iğne giriş işlemi sırasında hissedilen, tetik nokta enjeksiyonu sirasında hissedilen), premenstruel sendrom (PMS) ile baş etme, epizyotomi iyileşme süresi, huzursuz bacak sendromu şiddeti, vital bulgular, oksijen satürasyonu, ajitasyon, anksiyete-kayg1, konfor, kortizol ve memnuniyet düzeyi üzerine olan etkilerini değerlendirmek amacıyla kullanıldığ görülmektedir. Çalışmalar kapsamında değerlendirilen parametrelerin, literatürde lavantanın etkili olduğu belirtilen durumlar ile benzer olduğu, bu nedenle araştırmacılar tarafindan sıcça kullanıldığ düşünülmektedir. Ayrıca lavanta ve çay ağacı yağı dışındaki uçucu yağların, oldukça güçlü olması nedeniyle özellikle uygun şekilde dilue edilmeden kullanımına bağlı olarak ciltte irritasyon oluşturacağı bildirilmektedir (2). Yapılan tezlerde lavanta yağının sık kullanım nedenlerinden birinin de uygulama sırasında bireylerde oluşacak beklenmedik etkilerin oluşumunu önlemek amaciyla olduğu düşünülmektedir.

Doktora tezlerinde aromaterapinin etkinliğini değerlendirmek amacıyla ele alınan konuların çoğunlukla ağr1, yorgunluk, bulantı-kusma ve anksiyete olduğu; yüksek lisans tezlerinde ise ağrı, uyku ve kaygı olduğu belirlenmiştir. İncelenen tez çalışmalarının tamamına yakınında uygulanan aromaterapinin ağrı $(12,13,17,18$, $20,22-24,27,28)$, yorgunluk $(11,12)$, anksiyete ve kayg1 $(18,21,27)$ düzeyini azalttığı, uyku kalitesini $(11,21,27)$ arttırdığ1, bulantı-kusmada etkili olduğu saptanmıştır. Bu sonuçlara paralel olarak literatürde aromaterapi kullanımının ağrı (30-32), yorgunluk (33) ve anksiyetekayg1 (30, 31, 34) düzeyini azalttığ1, uyku kalitesini artırdığı (34, 35), bulantı-kusmada azalmayı (36) sağladığı belirtilmektedir.

Ayrıca tez çalışmalarının bazılarında aromaterapi uygulamasının bazı yönlerden de etkili olmadığı saptanmıştır. İzgü (17) kemoterapi alan kanser hastalarına uygulanan aromaterapi masajının periferal nöropatik ağrı görülme sıklığını ve ağrı şiddetini azalttığını, fakat yorgunluk şiddetini etkilemediğini saptamıştır. Khiewkhern ve ark. (37) kemoterapi tedavisi alan kolorektal kanser hastalarına zencefil yağı kullanılarak yapılan aromaterapi masajının yorgunluk, ağrı ve stres gibi semptomları azaltmada etkili olduğu bildirilmiştir. Kasar (18)'ın çalışmasında ise miyofasiyal ağrı sendromu olan hastalara tetik nokta enjeksiyonu sırasında inhaler olarak uygulanan lavanta yağının; ağrı şiddetini, anksiyete ve stres düzeyini azalttığ 1 , konfor düzeyini ve hasta memnuniyetini arttırdığı ancak tükürük kortizol sonuçlarında anlamlı bir fark oluşturmadığ belirlenmiştir. Jafarzadeh ve ark. (38) diş tedavisi gören çocuklara portakal yağı ile uygulanan aromaterapinin tükrük kortizol düzeyini azalttığını belirlemiştir. Yapılan başka bir çalışmada da hiperaktivite bozukluğu olan çocuklara lavanta ve sardunya yağı kullanılarak uygulanan aromaterapi masajının tükrük kortizol düzeyini anlamlı düzeyde azalttığı saptanmıştır (39). Araştırma sonuçlarında aromaterapi etkinliğinin, kullanılan esansiyel yağın çeşidi ve hasta özelliklerinden kaynaklanabileceği düşünülmektedir. $\mathrm{Bu}$ durum farklı örneklem grupları ile farklı aromatik yağlar ve yöntemler kullanılarak yüksek kanıt düzeyli daha fazla çalışma yapılması gerekliliğini düşündürmektedir. 
Kemoterapi, kanser tedavisinde primer ve adjuvan kemoterapi olarak sıklıkla kullanılan bir tedavi yöntemi olup, istenmedik birçok semptoma neden olabilmektedir (40). Bu semptomların yönetiminde hem hastalar hem de hemşireler tarafından non-farmakolojik sağlık uygulamaları sıkça kullanılmaktadır. İncelenen doktora tez çalışmalarında da $(13,16,17,19)$ aromaterapi uygulamalarının en fazla kanser hastalarıyla yürütüldügüü, özellikle de aromaterapinin kemoterapiye bağlı ortaya çıkan bazı semptomlar üzerindeki etkisini belirlemek amacıyla yapıldı̆̆ı saptanmıştır. Kemoterapik ilaçlara bağlı olarak ortaya çıkan semptomların yönetiminde, farmakolojik ajanların yanı sıra non-farmakolojik yöntemlere de yer verilmesi, bireylerin kullandığı ilaç miktarını azaltarak, fiziksel sağlığının korunmasına katkı sağlayacaktır.

\section{SONUÇ}

Türkiye'de hemşirelik alanında yapılan randomize kontrollü lisansüstü tezlerin tamamına yakınında aromaterapi uygulamalarının kullanım amacına göre etkili olduğu belirlenmiştir. Bu doğrultuda klinisyen hemşirelere aromaterapi konusunda gerekli eğitimler verilmesi ve bu uygulamalarla ilgili yetkinlik kazanmalarının desteklenmesi gerekmektedir. Kanıt temelli bilgilerle standart bakım uygulamalarına entegre edilen aromaterapi uygulamaları, bakım kalitesi ile hasta memnuniyetinin artırılmasını ve hastalık semptomlarının azaltılmasını sağlayacaktır. $\mathrm{Bu}$ bağlamda hemşirelik alanında yapılmış kanıt düzeyi yüksek, lisansüstü ve diğer akademik çalışmaların sayıca arttırılması gerektiği düşünülmektedir.

Yazar Katkıları: Fikir/Kavram A.K., S.K.K., Tasarım A.K., S.K.K., Veri Toplama ve/veya İşleme A.K., S.K.K., Analiz ve/veya Yorum A.K., S.K.K., Literatür Taraması A.K., S.K.K., Makale Yazımı A.K., S.K.K., Eleştirel İnceleme A.K., S.K.K.

\section{KAYNAKLAR}

1. Baltacı N, Deniz HT. Tamamlayıcı ve bütünleşik bir bakım uygulaması: Aromaterapi. International Social Sciences Studies Journal. 2019; 5(32): 1802-9.

2. Berman A, Snyder SJ, Frandsen G, editors. Complementary and alternative healing modalities. In: Kozier \& Erb's fundamentals of nursing: concepts, practice, and process. 10th Edition. New Jersey: Pearson Education; 2016. p. 295-300.

3. National Center for Complementary and Integrative Health. [Internet]. [Updated: 2020 Jan; Cited: 2020 May 1]. Available from: https://www.nccih.nih.gov/health/aromatherapy.

4. Başaran A. Natural aromatherapy: Herbs \& essences. Turkiye Klinikleri J Med Sci. 2009; 29(Suppl): 86-94.

5. Gnatta JR, Kurebayashi LFS, Turrini RNT, Silva MJP. Aromatherapy and nursing: Historical and theoretical conception. Rev Esc Enferm USP. 2016; 50(1): 127-33.

6. Bilgiç Ş. Hemşirelikte holistik bir uygulama; aromaterapi. Namık Kemal Tıp Dergisi. 2017; 5(3) 134-41.

7. Özdemir H, Öztunç G. Hemşirelik uygulamalarında aromaterapi. Turkiye Klinikleri J Nurs Sci. 2013; 5(2): 98-104.
8. Nahcivan N. Nicel araştırma tasarımları. Erdoğan S, Nahcivan N, Esin MS, editörler. Hemşirelikte araştırma; süreç, uygulama ve kritik. 2. Baskı. İstanbul: Nobel Tıp; 2015. s.112.

9. Seçginli S. Hemşirelikte araştırma kullanımı ve kanıta dayalı uygulamalar. Erdoğan S, Nahcivan N, Esin MS, editörler. Hemşirelikte araştırma; süreç, uygulama ve kritik. 2. Baskı. İstanbul: Nobel Tip; 2015. s.343-5.

10. Tosun Ö. Aromaterapi, müzikterapi ve vibrasyon uygulamalarının yenidoğanın stres ve davranışları üzerine etkisi [Doktora tezi]. Kayseri: Erciyes Üniversitesi; 2013.

11. Muz G. Hemodiyaliz tedavisi alan bireylerde inhalasyon yoluyla uygulanan aromaterapinin uyku kalitesi ve yorgunluk düzeyine etkisi [Doktora tezi]. Kayseri: Erciyes Üniversitesi; 2015.

12. Metin ZG. Romatoid artritli hastalarda aromaterapi masajı ve refleksoloji uygulamalarının ağrı ve yorgunluğa etkileri [Doktora tezi]. Ankara: Hacettepe Üniversitesi; 2015.

13. Yayla EM. İnhaler yolla uygulanan aromaterapinin implante edilebilir venöz port kateter iğne girişine bağlı prosedürel ağrı ve anksiyete üzerine etkisi [Doktora tezi]. Ankara: Hacettepe Üniversitesi; 2016.

14. Kaymaz TT. Orta ve ileri evre demans hastalarına uygulanan aromaterapinin ajitasyon ve bakım verenin yüküne etkisi [Doktora tezi]. Ankara: Hacettepe Üniversitesi; 2016.

15. Uzunçakmak $T$. Üniversite öğrencilerine uygulanan aromaterapinin premenstruel sendrom ile baş etmeye etkisi [Doktora tezi]. Ankara: Gazi Üniversitesi; 2016.

16. Zorba P. Masaj ve inhaler yollarla uygulanan aromaterapinin kemoterapiye bağlı akut bulantı kusmaya etkisinin karşılaştırılması [Doktora tezi]. Ankara: Hacettepe Üniversitesi; 2016.

17. İzgü N. El ve ayağa uygulanan aromaterapi masajının kemoterapi ilişkili periferal nöropatik ağrı ve yorgunluk üzerine etkisi [Doktora tezi]. Ankara: Hacettepe Üniversitesi; 2017.

18. Kasar KS. Miyofasiyal ağrı sendromu olan bireylerde tetik nokta enjeksiyonu sirasinda uygulanan inhaler aromaterapinin ağrl, anksiyete, konfor ve kortizol düzeyine etkisi [Doktora tezi]. İzmir: Ege Üniversitesi; 2018.

19. Ertürk NE. Kemoterapi alan hastalara uygulanan nane yağının bulantı kusma ve öğürme üzerine etkisi [Doktora tezi]. Kayseri: Erciyes Üniversitesi; 2019.

20. Sönmez DZ. Diz osteoartriti olan bireylere diz bölgesine lokal olarak uygulanan sarı kantaron yağının ağrı şiddetine ve fiziksel fonksiyonlara etkisi [Doktora tezi]. Kayseri: Erciyes Üniversitesi; 2019.

21. Ayik C. Ameliyat öncesi dönemde aromaterapi masajının anksiyete ve uyku kalitesine etkisinin incelenmesi [Yüksek lisans tezi]. İzmir: Dokuz Eylül Üniversitesi; 2016.

22. Eminov A. Epizyotomi bakımında kullanılan lavanta yağı ve buz uygulamasının epizyotomi ağrısına etkisi [Yüksek lisans tezi]. İzmir: Ege Üniversitesi; 2017.

23. Cenkci Z. Aromaterapinin doğum eylemindeki ağrı, konfor ve memnuniyet üzerine etkisi [Yüksek lisans tezi]. Adana: Çukurova Üniversitesi; 2017. 
24. Taşan E. İnhaler lavantanın hemodiyaliz hastalarında damara ulaşım sırasında oluşan ağrıya etkisi [Yüksek lisans tezi]. Gaziantep: Gaziantep Üniversitesi; 2018.

25. Gülşen G. Üst gastrointestinal endoskopi işlemi uygulanan hastalara müzik eşliğinde uygulanan inhaler aromaterapinin vital bulgulara etkisi [Yüksek lisans tezi]. Gaziantep: Gaziantep Üniversitesi; 2018.

26. Erat A. Hemodiyaliz tedavisi alan bireylerde lavanta yağı ile uygulanan masajın huzursuz bacak sendromu şiddeti ve yaşam kalitesine etkisi [Yüksek lisans tezi]. Kayseri: Erciyes Üniversitesi; 2019.

27. Baykal FC. Aromaterapi masajının kronik nonmalign ağrısı olan hastalarda ağrı, anksiyete ve uyku kalitesi üzerine etkisinin incelenmesi [Yüksek lisans tezi]. İzmir: Ege Üniversitesi; 2019.

28. Özdemir ST. Hemodiyaliz hastalarında av fistül uygulaması sırasında oluşan ağrıyı gidermede lavanta aromaterapinin etkisi [Yüksek lisans tezi]. İzmir: Ege Üniversitesi; 2019.

29. van der Watt G, Janca A. Aromatherapy in nursing and mental health care. Contemp Nurse. 2008; 30(1): 69-75.

30. Ziyaeifard M, Zahedmehr A, Ferasatkish R, Faritous Z, Alavi M, Alebouyeh MR, et al. Effects of lavender oil inhalation on anxiety and pain in patients undergoing coronary angiography. Iranian Heart Journal. 2017; 18 (1): 44-50.

31. Lamadah SM, Nomani I. The effect of aromatherapy massage using lavender oil on the level of pain and anxiety during labour among primigravida women. American Journal of Nursing Science. 2016; 5(2): 3744.

32. Chena SF, Wang CH, Chan PT, Chiang HW, Hu TM, Tam KW, et al. Labour pain control by aromatherapy: A meta-analysis of randomised controlled trials. Women and Birth. 2019; 32 (4) 327-35.

33. Eun-Ja L, Bok-Soon K, In-Hae S, Kyung-Eun M, Jeong-Hwa K. The effects of aromatherapy on sleep disorders, satisfaction of sleep and fatigue in hemodialysis patients. Korean J Adult Nurs. 2011; 23(6): 615-23.

34. Rajai N, Sajadi SA, Teymouri F, Zareiyan A, Siavoshi S, Malmir M. The effect of aromatherapy with lavender essential oil on anxiety and stress in patients undergoing coronary artery bypass graft surgery. Jundishapur J Chronic Dis Care. 2016; 5(4): e34035.

35. Afshar MK, Moghadam ZB, Taghizadeh Z, Bekhradi R, Montazeri A, Mokhtari P. Lavender fragrance essential oil and the quality of sleep in postpartum women. Iran Red Crescent Med J. 2015; 17(4): e25880.

36. Eghbali M, Varaei S, Yekaninejad MS, Mohammadzadeh F, Shahi F. To what extend aromatherapy with peppermint oil effects on chemotherapy induced nausea and vomiting in patient diagnosed with breast cancer? A randomized controlled trial. J Hematol Thrombo Dis. 2017; 5(6): 2-6.

37. Khiewkhern S, Promthet S, Sukprasert A, Eunhpinitpong W, Bradshaw P. Effectiveness of aromatherapy with light thai massage for cellular immunity improvement in colorectal cancer patients receiving chemotherapy. Asian Pacific J Cancer Prev. 2013; 14 (6): 3903-7.

38. Jafarzadeh M, Arman S, Pour FF. Effect of aromatherapy with orange essential oil on salivary cortisol and pulse rate in children during dental treatment: A randomized controlled clinical trial. Adv Biomed Res. 2013; 2: 10.

39. Wu JJ, Cui Y, Yang YS, Kang MS, Jung SC, Park HK, et al. Modulatory effects of aromatherapy massage intervention on electroencephalogram, psychological assessments, salivary cortisol and plasma brain-derived neurotrophic factor. Complementary Therapies in Medicine. 2014; 22(3): 456-62.

40. Akdemir N. Kanser tedavileri ve hemşirelik bakımı. Akdemir N, Birol L, editörler. İç hastalıkları ve hemşirelik bakımı. Genişletilmiş 3. Baskı. Ankara: Sistem Ofset; 2011. s. 265. 